\title{
Fermentation of methoxyacetate to glycolate and acetate by newly isolated strains of Acetobacterium sp.
}

\author{
Beate Schuppert* and Bernhard Schink \\ Lehrstuhl Mikrobiologie I der Eberhard-Karls-Universität, Auf der Morgenstelle 28, D-7400 Tübmgen, Federal Republic of Germany
}

\begin{abstract}
Three strains of new mesophilic homoacetogenic bacteria were enriched and isolated from sewage sludge and from marine sediment samples with methoxyacetate as sole organic substrate in a carbonate-buffered medium under anoxic conditions. Two freshwater isolates were motile, Gram-positive, non-sporeforming rods. The marine strain was an immotile, Gram-positive rod with a slime capsula. All strains utilized only the methyl residue of methoxyacetate and released glycolic acid. They also fermented methyl groups of methoxylated aromatic compounds and of betaine to acetate with growth yields of 6-10 g dry matter per mol methyl group. $\mathrm{H}_{2} / \mathrm{CO}_{2}$, formate, methanol, hexamethylene tetramine, as well as fructose, numerous organic acids, glycerol, ethylene glycol, and glycol ethers were fermented to acetate as well. High activities of carbon monoxide dehydrogenase $\left(0.4-2.2 \mathrm{U} \times \mathrm{mg}\right.$ protein $\left.{ }^{-1}\right)$ were detected in all three isolates. The guanine-plus-cytosine-content of the DNA of the freshwater isolates was 42.7 and $44.4 \mathrm{~mol} \%$, with the marine isolate it was $47.7 \mathrm{~mol} \%$. The freshwater strains were assigned to the genus Acetobacterium as new strains of the species $A$. carbinolicum. One freshwater isolate, strain KoMac1, was deposited with the Deutsche Sammlung von Mikroorganismen $\mathrm{GmbH}$, Braunschweig, under the number DSM 5193.
\end{abstract}

Key words: Anaerobic ether cleavage - Methoxyacetate 2-Methoxyethanol - Demethylation - Homoacetogenic bacteria - Acetobacterium sp.

Ether linkages are cleaved aerobically usually by oxygenase reactions which hydroxylate one of the vicinal ether carbon atoms and thus transform the ether compound into a comparably unstable hemiacetal structure (Heydeman 1974). Accordingly, phenylmethyl ethers such as lignin monomers are aerobically oxidized to the corresponding phenols and formaldehyde (Axclrod 1956; Cartwright and Smith 1967; Bernhardt et al. 1970; Taylor 1983; Sutherland 1986).

Acetobacterizm woodii was the first bacterium reported to be able to cleave phenylmethyl ether linkages in the ab-

\footnotetext{
* Present address: Fraunhofer-Institut fïr Grenzflächen- und Bioverlahrenstcchnik, Nobclstr. 12, D-7000 Stuttgart 80, FRG

Offprint requests to: B. Schink
}

sence of molecular oxygen, and to ferment the methyl residues, analogous to methanol, with $\mathrm{CO}_{2}$ to acetate (Bache and Pfennig 1981). Similar findings were made later on with other homoacetogenic bacteria (Krumholtz and Bryant 1985; Frazer and Young 1985, 1986; Mountfort and Asher 1986) and even with an Enterobacter strain (Grbic-Galic and LaPat-Polasko 1985). All these bacteria could remove the methyl groups only from aromatic methyl ethers; cleavage of methyl alkyl ethers was never observed.

Another case of anaerobic ether cleavage was observed with polyethylene glycol degradation by Pelobacter venetianus (Schink and Stieb 1983). The lirst degradation intermediate detected was acetaldehyde, suggesting that the terminal hydroxyl group of the polymer is shifted to the subterminal carbon atom, analogous to a diol dehydratase reaction, which in this case transforms the ether linkage again into a hemiacetal bond (Straß and Schink 1986). It was shown by feeding experiments that anderobic polyethylene glycol degradation depended on a free terminal hydroxyl function, and that terminally methylated polyethylene glycols were not degraded. A different pathway of anaerobic polyethylene glycol degradation was assumed to occur in other fermenting and sulfate-reducing bacteria, however, the ether cleavage reaction was not studied (Dwyer and Tiedje 1986).

In the present study, we chose methoxyacetate as a model substrate of a methylalkylether which cannot be attacked by a diol dehydratase because it does not contain a frec alcohol function. New strains of homoacetogenic bacteria were isolated which degraded methoxyacetate, and very slow anaerobic degradation was also found in enrichment cultures with dimethoxyethane.

\section{Materials and methods}

\section{Sources of organisms}

Strains KoMac1 and GöMac1 were enriched and isolated from anoxic digestor sludges of municipal sewage plants at Göttingen and Konstanz, FRG, respectively. Strain RMMacl was isolated from a saltwater sediment sample taken from Rio Marin in the city of Venice, Italy. An enrichment culture degrading dimethoxyethane (culture WoDME) was obtained with an inoculum from a polluted freshwater creek near Konstanz, FRG. 


\section{Media and growth conditions}

All procedures for cultivation and isolation as well as all methods for analysis of metabolic products were essentially as described in earlier papers (Widdel and Pfennig 1981; Schink and Pfennig 1982). The mineral medium for enrichment, isolation and cultivation contained $30 \mathrm{mM}$ sodium bicarbonate as buffer, $1 \mathrm{mM}$ sodium sulfide as reducing agent, the trace element solution SL 10 (Widdel et al. 1983) and a vitamin solution (Pfennig 1978). Freshwater medium contained $0.5 \mathrm{~g} \mathrm{NaCl}$ and $0.4 \mathrm{~g} \mathrm{MgCl}_{2} \times 6 \mathrm{H}_{2} \mathrm{O}$, saltwater medium $20.0 \mathrm{~g}$ and $3.0 \mathrm{~g}$, respectively, per liter. The $\mathrm{pH}$ was $7.1-7.3$. Growth experiments were carried out at $30^{\circ} \mathrm{C}$. For isolation of pure cultures, the agar shake dilution method was applied (Pfennig 1978). Gram staining was carried out after Magee et al. (1975); the Gram type was also checked by the KOH method (Gregersen 1978).

\section{Chemical determinations and chemicals}

Sulfide was determined after Cline (1969), nitrite after Procházková (1959), protein after Zamenhoff (1957), carbon monoxide dehydrogenase after Dickert and Thauer (1978). Fatty acids and methoxyacetate were determined by direct gas chromatography on a packed column (Schink and Plennig 1982), glycolic acid on a glas capillary column after methylation (Dehning and Schink 1989).

All chemicals used were of analytical or reagent grade quality and were obtained from Merck, Darmstadt, Sigma, München, and Fluka, Neu-Ulm, FRG.

\section{Results}

\section{Enrichment and isolation}

Enrichment cultures with freshwater or saltwater medium containing $10 \mathrm{mM}$ methoxyacetate were inoculated with about $5 \mathrm{ml}$ sediment and sludge samples from various sources, including marine and freshwater sediments, as well as sewage sludge from two municipal sewage plants. Gas production started in all cases after 3-5 weeks, and subcultures were subsequently inoculated with $5 \mathrm{ml}$ culture fluid, usually after $2-3$ weeks of incubation. Pure cultures were isolated from these cultures by two subsequent agar shake dilution series with methoxyacetate as substrate.

Freshwater cultures formad yellowish lens-shaped colonies, marine cultures small white colonies in the agar. Pure cultures were finally obtained with the enrichment cultures from two sewage plants (strains KoMac1 and GöMac1) and from Rio Marin, Venice (strain RMMac1). Purity was checked by microscopical examination after growth in minimal medium and in complex medium (AC- medium, Difco, Ann Arbor, Michigan, USA).

Similar enrichment cultures with dimethoxyethane (ethylene glycol dimethyl ether) exhibited gas production only in one case (sediment from a polluted freshwater creek) after 5 months of incubation. The dimethoxyethane-degrading bacteria could be transferred over 16 subcultures with cultivation times of 4-6 weeks every time. Pure cultures could not be isolated. In the enrichment cultures, complete conversion to $\mathrm{CH}_{4}$ and $\mathrm{CO}_{2}$ with intermediate formation of acetate could be demonstrated (data not shown).

\section{Cytological properties of pure cultures}

The two freshwater strains KoMac1 and GöMac1 were motile rods, $0.9-1.0 \times 2.0-4.0 \mu \mathrm{m}$ in size, with slightly pointed ends (Fig. 1a, b). In older cultures, they tended to form chains of several cells which were sometimes swolien in the middle. Both strains stained Gram-positive; results of the $\mathrm{KOH}$ test indicated a Gram-positive cell wall architecture as well. Cells of strain RMMac1 were immotile, rather small rods, $0.5-0.7 \times 1-1.5 \mu \mathrm{m}$ in size, with rounded ends (Fig. 1c). They stained Gram-negative, but both the $\mathrm{KOH}$ test as well as electron microscopic examination indicated a Gram-positive cell wall architecture (Fig. 2). In Indian ink prcparations, thin slime capsules became visible. No strain formed spores, neither in defined medium nor in a special sporulation medium (Hollaus and Sleytr 1972). Pasteurized cultures did not show growth after more than 6 weeks of incubation. The guanine-plus-cytosine content of the DNA was $42.7 \pm 1.0 \mathrm{~mol} \%$ with strain KoMac1, $44.4 \pm 1.0 \mathrm{~mol} \%$ with strain GöMac1, and $47.8 \pm 1.0 \mathrm{~mol} \%$ with strain RMMac1. No cytochromes could be detected by redox difference spectroscopy of crude cell extracts of either strain.

\section{Physiology}

The strains KoMact and RMMac1 grew well in mincral. medium containing $\mathrm{NaCl}$ from 0.05 up to $2.0 \%$ and $\mathrm{MgCl}_{2} \times 6 \mathrm{H}_{2} \mathrm{O}$ from 0.04 to $0.3 \%$ (w/v), strain GöMac1 grew in medium with $0.05-1.5 \% \mathrm{NaCl}$ and $0.04-0.4 \%$ $\mathrm{MgCl}_{2} \times 6 \mathrm{H}_{2} \mathrm{O}$. Phosphate inhibited growth of strains
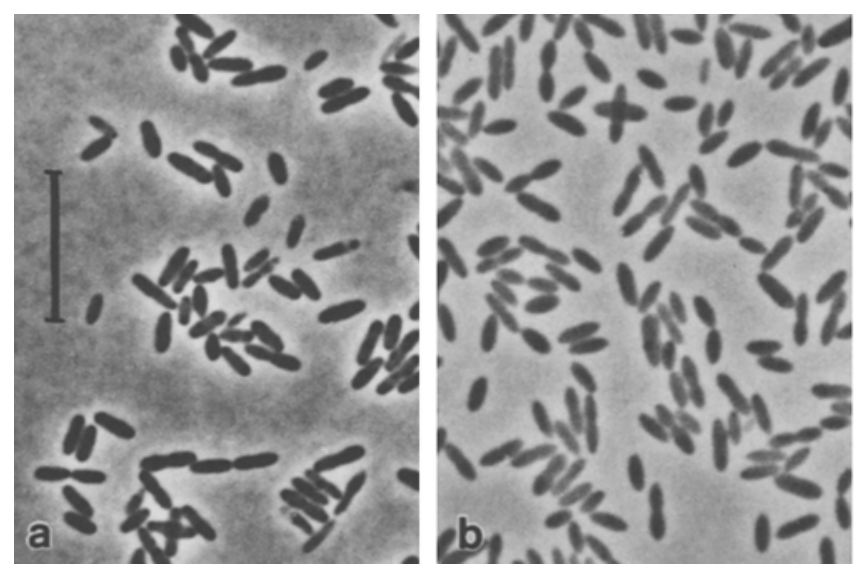

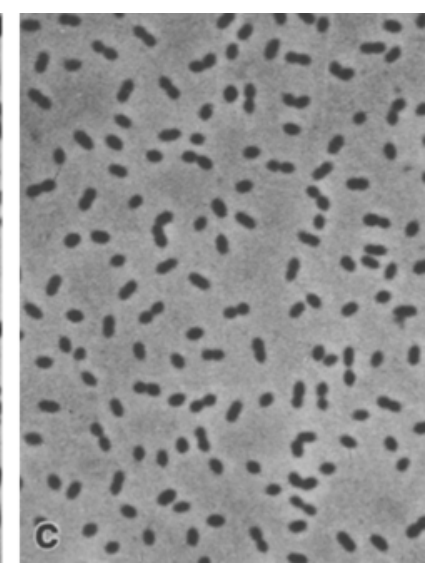

Fig. 1 $\mathrm{d}-\mathrm{c}$

Phase-contrast photomicrographs of cells of the new isolates. a Strain KoMac1, b GôMac1, e strain RMMac1. Bar equals 10 um for all three pictures 


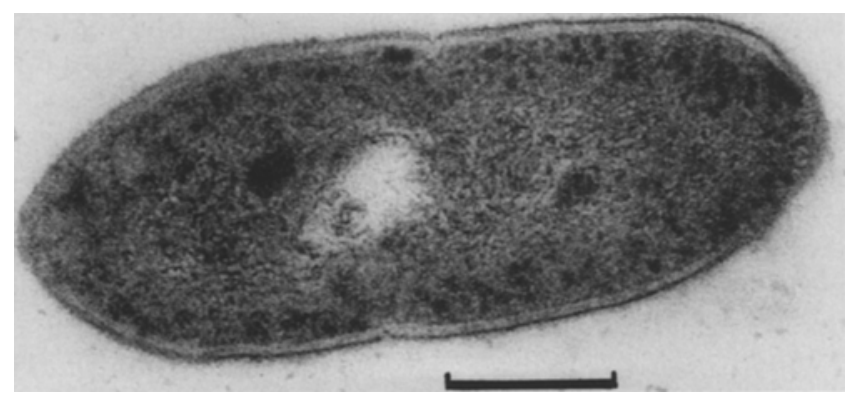

Fig. 2. Electron micrograph of an ultrathin section of cells of strain RMMac1. Bar equals $0.2 \mu \mathrm{m}$

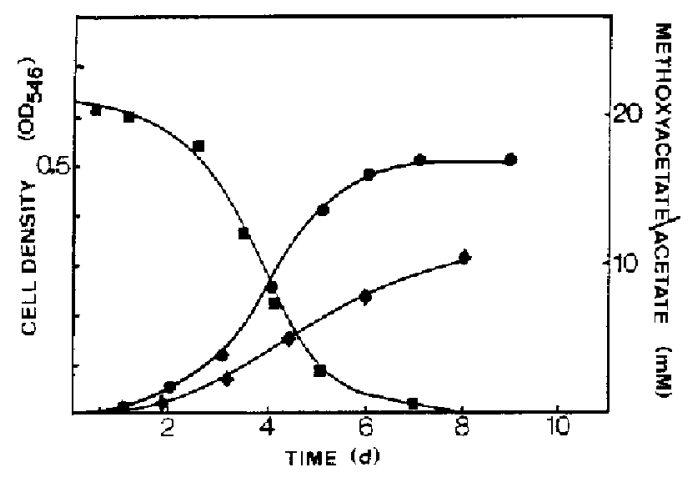

Fig. 3. Fermentation time course of strain KoMacl growing with methoxyacetate. Experiments were performed at $30^{\circ} \mathrm{C}$ in half-filled $100 \mathrm{ml}$ culture bottles with rubber septa. Samples were taken at times indicated and the headspaces were flushed with $\mathrm{N}_{2} / \mathrm{CO}_{2}$ gas

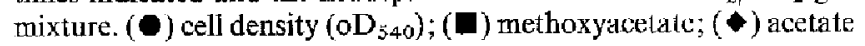

Table 1. Substrates tested for growth with the new strains KoMac1, GöMac1, and RMMac1. All tests were carricd out in mineral medium with $0.05 \%(\mathrm{w} / \mathrm{v})$ yeast extract

\begin{tabular}{lccc}
\hline Substrate degraded & KoMac1 & GöMacl & RMMac1 \\
\hline $\mathrm{H}_{2} / \mathrm{CO}_{2}$ & + & + & + \\
Formate & + & + & - \\
Hexamethylene tetramine & + & - & - \\
Methanol & + & + & + \\
Methoxyacetate & + & + & + \\
Vanillate & + & + & + \\
Syringale & + & + & - \\
Sinapinate & + & + & - \\
Trimethoxybenzoate & + & + & - \\
Betaine & + & + & + \\
Ethanol & + & - & - \\
Lactate & + & + & - \\
Pyruvate & + & + & + \\
D, L-Malate & + & + & + \\
Fumarate & - & - & + \\
Fructose & + & + & - \\
Glycerol & + & + & - \\
Triacetin & + & + & - \\
Ethylene glycol & + & + & - \\
Diethylene glycol & + & + & - \\
Triethylene glycol & + & - & - \\
Ethoxyethanol & + & + & - \\
Nayol & + & &
\end{tabular}

No growth was found with the following substrates: Dimethoxyethane, diethoxyethane, 1-propanol, 1-butanol, glucose, arabinose, xylose, glycolate, glycine, ethanolamine, trimethylamine, citrate, D-erythritol
KoMac1 and RMMac1 at $>30 \mathrm{mM}$, of strain GöMacl at $>10 \mathrm{mM}$ concentration. Yeast extract was not required for growth, but all strains grew faster and to higher cell densities in the presence of yeast extract. Optimal growth with methoxyacetate was found at $30^{\circ} \mathrm{C}$ with the following growth rates and doubling times. Strains GöMacl and KoMac1 : $\mu=0.049 \mathrm{~h}^{-1}, t_{\mathrm{d}}=14 \mathrm{~h}$; strain RMMac1 : $\mu=$ $0.037 \mathrm{~h}^{-1}, t_{\mathrm{d}}=19 \mathrm{~h}$. The temperature limits of growth were 15 and $34^{\circ} \mathrm{C}$, the $\mathrm{pH}$ optima $6.8-7.0$, and the $\mathrm{pH}$ ranges from $6.0-8.0$ with the freshwater isolates and $6.6-7.4$ with strain RMMac1.

The substrates utilized by the various strains are listed in Table 1. Besides those substrates used by many other homoacetogenic bacteria, methoxyacetate and betaine were found to be used as growth substrates. The methoxylated aromatic compounds were fermented to the corresponding phenols. UV spectrophotometric cxamination indicated that the acrylic acid side chain of sinapic acid was reduced to trihydroxyphenylpropionic acid. Hexamethylene tetramine was used as a formaldehyde-yielding substrate; many homoacetogenic bacteria ferment formaldehyde to acetate (Schink 1987). Neither nitrate, sulfate, sulfite, thiosulfate, nor sulfur was reduced during growth with methoxyacetate. Strain KoMac1 appeared to be the metabolically most versatile isolate. In Fig. 3, a growth curve of this strain growing with methoxyacetate is shown. Similar results were obtained with the other isolates.

Acetate was the main or sole fermentation product in all cases. Fermentation balances and growth yields were measured with all isolates. In Table 2, the data obtained with strain KoMac1 are presented. Similar results were obtained with the other strains as well. The amounts of products formed indicated that the substrates werc fermented completely. The methyl groups of all methoxyaromatics, methoxyacetate, and betaine were fermented with $\mathrm{CO}_{2}$ to acetate, in the same manner as methanol, but the cell yields obtained were by nearly $50 \%$ higher than with methanol.

Carbon monoxide dehydrogenase activity was detected in crude extracts of cells of all three isolates grown with methoxyacetate. The specific activities ( $\mu$ mol CO oxidized per min and mg protein) were 1.1 with strain KoMac1, 2.2 with strain GöMac1, and 0.37 with strain RMMac1.

\section{Discussion \\ Physiology and taxonomy of the new isolates}

In the present study, anaerobic degradation of methylalkyl ether compounds is documented for the first time. Three strains of homoacetogenic bacteria are described which ferment methoxyacetate with carbon dioxide to glycolate and acetate, according to the following equation (all calculations of free energy changes after Thauer et al., 1977; Dimroth 1983):

$$
\begin{aligned}
& 4 \mathrm{CH}_{3} \mathrm{OCH}_{2} \mathrm{COO}^{-}+2 \mathrm{CO}_{2}+2 \mathrm{H}_{2} \mathrm{O} \\
& \rightarrow 4 \mathrm{HOCH}_{2} \mathrm{COO}^{-}+3 \mathrm{CH}_{3} \mathrm{COO}^{-}+3 \mathrm{H}^{+} ;
\end{aligned}
$$

$\Delta \mathrm{G}_{0}^{\prime}=-85.2 \mathrm{~kJ}$ per mol methoxyacetate .

The free energy change of this reaction is considerably higher than that of the analogous fermentation of methanol and $\mathrm{CO}_{2}$ to acetate and water $\left(\Delta \mathrm{G}_{0}^{\prime}=-55.5 \mathrm{~kJ}\right.$ per mol methanol). 
Table 2. Stoichiometry of substrate conversion and growth yields of strain KoMac1 with various substrates

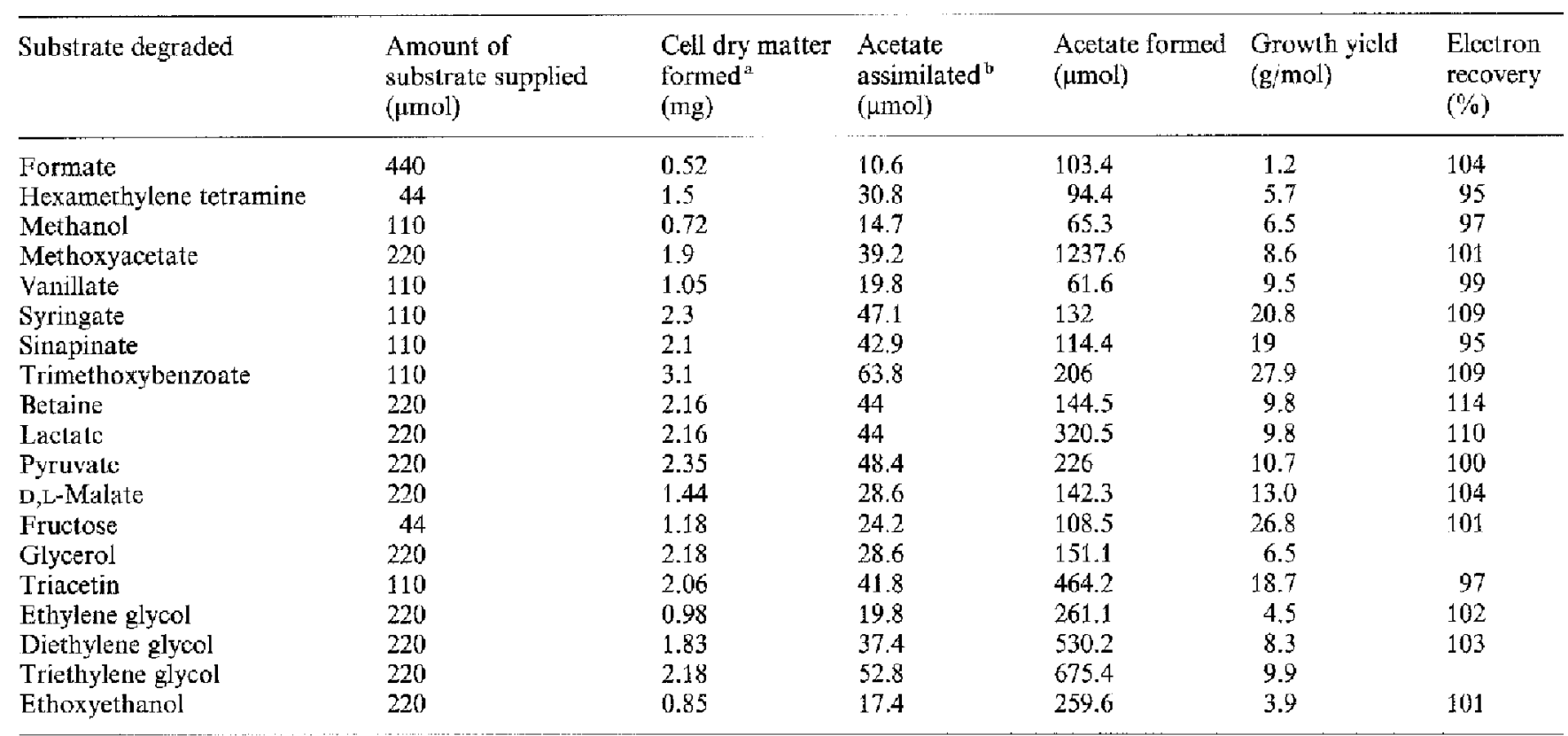

All growth experiments werc carricd out in screw cap tubes containing $22 \mathrm{ml}$ mineral medium with $0.05 \%$ yeast extract

a Cell dry matter values were calculated via cell density using an experimentally determined conversion factor $(0.1$ oD $540=29.7 \mathrm{mg}$ dry matter il)

Acetate assimilated was calculated according to the formula: $17 \mathrm{CH}_{3} \mathrm{COO}+17 \mathrm{H}^{+} \rightarrow 8\left\langle\mathrm{C}_{4} \mathrm{H}_{7} \mathrm{O}_{3}\right\rangle+2 \mathrm{CO}_{2}+6 \mathrm{H}_{2} \mathrm{O}$

The product of betaine fermentation was not identified From the stoichiometry of acetate formation, it appears that only one methyl group per substrate molecule was fermented and therefore dimethylglycine was formed as demethylated product:

$4\left(\mathrm{CH}_{3}\right)_{3} \mathrm{~N}^{+} \mathrm{CH}_{2} \mathrm{COO}^{-}+2 \mathrm{CO}_{2}+2 \mathrm{H}_{2} \mathrm{O} \rightarrow$ $4\left(\mathrm{CH}_{3}\right)_{2} \mathrm{~N}^{+} \mathrm{HCH}_{2} \mathrm{COO}^{-}+3 \mathrm{CH}_{3} \mathrm{COO}^{-}+3 \mathrm{H}^{+}$.

A similar methyl group fermentation pattern was found with Eubacterium linosum (Müller et al. 1981) and Acetobacterium carbinolicum (Eichler and Schink 1984).

The newly isolated homoacetogens differ from those of the species described so far by their ability to demethylate methoxyacetate to glycolate. Our freshwater isolates resemble A. carbinolicum most among the described types of homoacetogens, also with respect to triacetin utilization (Emde and Schink 1987), and we suggest that they should be grouped with this species as new biotypes. The taxonomic status of the morphologically atypical marine isolate RMMac1 would require further studies. Strain KoMac1 was deposited with the Deutsche Sammlung für Mikroorganismen GmbH, Braunschweig, under the number DSM 5193.

\section{Biochemistry of anaerobic methylether cleavage}

The chemistry of anaerobic phenylmethyl ether cleavage by homoacetogenic bacteria is not yet understood. Ether linkages are too stable to be split by a simple hydrolysis reaction. Studies on kinetics and yields of growth of $A$. woodii on phenylmethyl ether compounds and on methanol indicated that free methanol is not an intermediate (Tschech and Pfennig 1984). Degradation experiments with Eubacterium limosum on ${ }^{18} \mathrm{O}$-labelled methoxybenzoates demonstrated recently that the ether oxygen stays with the aromatic ring and is not released into acetate or water (deWeerd et al. 1988). This supports the concept that the ether linkage is not cleaved by a hydrolysis reaction but that the methyl residue is transferred directly to a methyl carrier such as coenzyme $B_{12}$, possibly as a methyl radical. A similar chemistry of ether linkage cleavage must be involved in methoxyacetate degradation by our new isolates.

It is open at present whether all the demethylation rcaetions carried out by our new isolates are catalyzed by the same enzyme system. From the fermentation stoichiometries and growth yields it is obvious that methyl groups bound to nitrogen or ether oxygen give about $50 \%$ higher growth yields than methanol, in close agreement with the free energy changes of these reactions (see above). This rules out again a formation of free methanol as intermediate in demethylation and indicates that methanol, unlike the linked methyl groups, has to be transferred to a methyl carrier by an energy-consuming system. Cross-feeding experiments with cell suspensions grown with either methyl substrate indicated that separate demethylating activities had to be induced for methanol, vanijlic acid, methoxyacetate, and betaine, respectively (data not shown). However, since these specificities may as well be due to different substrate uptake systems, these results cannot rule out that a common enzyme system may be responsible for the respective demethylation and methyl group transfer reaclions.

Anaerobic demethylation of methoxyacetate by our new isolates opens a further pathway for methanogenic degradation of methoxy cthanol, an important industrial solvent. In anoxic sludge degrading this substrate, methoxyacetate was found and was assumed to be an intermediate product in a degradation pathway leading from methoxyethanol via 2-methoxyacetate and glycolate to methane plus carbon dioxide, however, bacteria catalyzing such a reaction sequence could not be cultivated (Tanaka et. al. 1986). Instead, 2methoxyethanol-degrading homoacetogenic and other fer- 
menting bacteria isolated from this culture were found to use a different pathway similar to that of anaerobic polyethylene glycol degradation: they formed acetate and free methanol, probably via 1-methoxyethanol as intermediate (Tanaka and Pfennig 1988). Our new isolates prove that the pathway first. suggested is possible as well, and perhaps is used in the same culture to a minor extent. It is worth emphasizing that in both hypothetical pathways coenzyme $\mathrm{B}_{12}$ plays a key role in ether destabilization or ether cleavage.

The freshwater strain KoMac1 was deposited with the Deutsche Sammlung von Mikroorganismen GmbH, Braunschweig, under the number DSM 5193.

Acknowledgement. The authors are indebted to Prof. Dr. F. Mayer and his coworkers for electron microscopic examination of strain RMMac1.

\section{References}

Axelrod J (1956) The enzymic cleavage of aromatic ethers. Biochem J $63: 634-639$

Bache R, Pfennig N (1981) Selective isolation of Acetobacterium woodii on methoxylated aromatic acids and detcrmination of growth yiclds. Arch Microbiol 130:255-261

Bernhardt F-H, Staudinger H. Ulrich V (1970) Eigenschaften einer p-Anisat-Q-Demethylase im zellfreien Extrakt von Pseudomonas species. Hoppe-Seyler's Z Physiol Chem 351:467-478

Cartwright NJ, Smith ARW (1967) Bacterial attack on phenolic ethers. An enzyme system demethylating vanillic acid. Biochem J $102: 826-841$

Cline ID (1969) Spectrometric detcrmination of hydrogen sulfjde in natural waters. Limnol Oceanogr $14: 454-458$

Dehning I, Schink B (1989) Malonomonas rubra gen. nov. sp. nov., a microaerotolerant anaerobic bacterium growing by decarboxylation of malonate. Arch Microbiol 151:427-433

DeWeerd KA, Saxena A, Nagle DP, Suflita JM (1988) Metabolism of the ${ }^{18} \mathrm{O}$ methoxy substituent of 3-methoxybenzoic acid and other unlabelled methoxybenzoic acids by anaerobic bacteria. Appl Environ Microbiol 54:1237-1242

Diekert GB, Thawer RK (1978) Carbon monoxide oxidation by Clostridium thernoaceticum and Costridium formicoaceticum. J Bacteriol 136:597-606

Dimroth K (1983) Inkremente zur Berechnung der Bildungsenthalpien und der freien Bildungsenthalpien. In: D'Ans Lax Taschenbuch für Chemiker und Physiker. Bd. 2, Organische Verbindunget. 4. ed. Springer, Berlin Heidelberg New York, pp 997 1006

Dwyer DF, Tiedje JM (1986) Metabolism of polyethylene glycol by two anaerobic bacteria, a Desulfovibrio desulfuricans and a Bactereides sp. Appl Environ Microbiol 52:852-856

Eichler B, Schink B (1984) Oxidation of primary aliphatic alcohols by Acetobacterium carbinolicum, a homacetogenic anacrobe. Arch Microbiol 140:147-152

Emde R, Schink B (1987) Fermentation of triacetin and glycerol by Acetobacterim $\mathrm{sp}$. No energy is conserved by acetate excretion. Arch Microbiol 149:145-148

Frazer AC, Young LY (1985) A Gram-negative anaerobic bacterium that utilizes O-methyl substituents of aromatic acids. Appl Environ Microbiol 49:1345-1347

Frazer AC, Young LY (1986) Anacrobic $C_{1}$ metabolism of the O-methyl- ${ }^{14} \mathrm{C}$-labeled substituent of vanillate. Appl Environ Microbiol 51:84-87

Grbic-Galic D, LaPat-Polasko L (1985) Enerobacter cloacae DG6: a strain that transforms methoxylated aromatics under aerobic and anaerobic conditions. Curr Microbiol 12:321 - 324

Gregersen T (1978) Rapid method for distinction of Gram-negative Fron Gram-positive bacteria. Eur J Appl Microbiol Biotechnol $5: 123-127$
Heydeman MT (1974) Growth of soil bacteria on diethyl cther. J Gen Microbiol $81: \mathrm{IX}-\mathrm{X}$

Hollaus F, Sleytr V (1972) On the taxonomy and fine siructure of some hyperthermophilic saccarolytic clostridia. Arch Mikrobiol $86: 129-146$

Krumholtz LR, Bryant MP (1985) Clostridium pfennigit sp. nov. uses methoxyl groups of mono-benzenoids and produces butyrate. Int J Syst Bacteriol 35:454-456

Magee CM, Rodehcaver G, Edgerton MT, Edlich RF (1975) A more reliable Gram staining technic for diagnosis of surgical infections. Am J Surgery 130:341-346

Mountfort DO, Asher RA (1986) Isolation from a methanogenic ferulate degrading consortium of an anaerobe that converts methoxyl groups of aromatic acids to volatile fatty acids. Arch Microbiol 144:55-61

Müller $\mathrm{E}$, Fahlbusch $\mathrm{K}$, Walther $\mathbf{R}$, Gottschalk $\mathrm{G}$ (1981) Formation of $\mathrm{N}, \mathrm{N}$-dimethylglycine, acetic acid, and butyric acid from betaine by Eubacterium limosum. Appl Environ Microbiol 42:439445

Pfennig N (1978) Rhodocyclus purpureus gen. nov. sp. nov., a ringshaped, vitamin $\mathrm{B}_{12}$-requiring member of the family $\mathrm{Rho}$ dospirillaceae. Int J Syst Bacteriol $28: 283-288$

Procházková L (1959) Bestimmung der Nitrate im Wasser. Z Anal Chem 167:254-260

Schink B (1987) Ecology of $\mathrm{C}_{1}$-metabolizing anaerobes. In: van Verseveld $\mathrm{HW}$, Duine JA (eds) Microbial growth on $\mathrm{C}_{1}$ compounds. Martinus Nijhoff Dordrecht, The Netherlands, pp 81 85

Schink B, Pfennig N (1982) Fermentation of trihydroxybenzenes by Pelobacter acidigalici gen. nov. sp. nov., a new strictly anacrobic, non-sporeforming bacterium. Arch Micrabiol 133:195201

Schink B, Stieb M (1983) Fermentative degradation of polyethyleneglycol by a new, strictly anaerobic, Gram-negative, nonsporeforming bacterium, Pelobacter venetianus sp. nov. Appl Environ Microbiol 45:1905-1913

Straß A, Schink B (1986) Fermentation of polyethylenc glycol via. acetaldchyde in Pelobacter venetianus. Appl Microbiol Biotechnol $25: 37-42$

Sutherland JB (1986) Demethylation of veratrole by cytochrome P-450 in Streptomyces setonii. Appl Environ Microbiol 52:98100

Tanaka K, Pfennig N (1988) Fermentation of 2-methoxyethanol by Acctobacterium malicum sp. nov. and Pelobacter venetionus. Arch Microbiol 149:181-187

Tanaka K, Mikami E, Suzuki T (1986) Methane fermentation of 2-methoxyethanol by mesophilic digesting sludge. J Ferment Technol 64:305-309

Taylor BF (1983) Aerobic and anaerobic catabolism of vanillic acid and some other methoxy-aromatic compounds by Pseudomonas sp. strain PN-1. Appl Environ Microbiol 46:1286-1292

Thauer RK, Jungermann K, Decker K (1977) Energy conservation in chemotrophic anaerobic bacteria. Bacteriol Rev 41:100180

Tschech A, Pfennig N (1984) Growth yielid increase linked to caffeate reduction in Acetebacterizm woodii. Arch Microbiol $137: 163-167$

Widdel, F, Pfennig N (1981) Studies on dissimilatory sulfate-reducing bacteria that decompose falty acids. I. Isolation of new sulfate-reducing bacteria enriched with acetate from saline environments. Description of Desulfobacter postgatei gen. nov. sp. nov. Arch Microbiol 129:395-400

Widdel F, Kohring GW, Mayer F (1983) Studies on dissimilatory sulfate-reducing bacteria that decompose fatty acids. III. Characterization of the filamentous gliding Desulfonema limicola gen. nov. sp. nov., and Desulfonema magmum sp. nov. Arch Microbiol 134:286-294

Zamenhoff S (1957) Preparation and assay of deoxyribonucleic acid from animal tissue. In: Colowick SP, Kaplan NO (eds) Methods in enzymology, vol 3. Academic Press, New York, pp 694-704

Received August 22, 1989/Accepted October 10, 1989 